\title{
Current status and challenges for LSDs in Bangladesh
}

\begin{abstract}
Background: With the fall of deaths of children from diarrhoea, respiratory tract infections and malnutrition due to availability of improved health services and diet, more children are now surviving and visiting hospital with genetic disorders. Lysosomal storage disorders represent a group of genetically distinct, biochemically related, inherited diseases. Individually, these disorders are considered rare, but collectively prevalence is 1 per 5,000-10,000. These disorders are devastating for individuals and their families and result in difficulties in diagnosis; however, the magnitude of the problem is not well defined.
\end{abstract}

Objective: To determine the current status and challenges regarding lysosomal storage disorders in Bangladesh.

Methodology: It was a retrospective study conducted in Dhaka Shishu (Children) Hospital from 2007 to 2016. Data of suspected neurometabolic disorders form hospital records and from child development and pediatric neuroscience department were included in the study. Patients profile and neurometabolic screening reports were collected. Challenges in diagnosis and managementwere noted. Data were analyzed by using SPSS

Results: Total 181 neurometabolic diseases were analyzed and different lysosomal storage disorders were found in $79(43.65 \%)$ individualswith male predominance (64\%). Majority were presented between 1 year to 5 years of age. H/O Consanguinity in $31 \%$, sibling death in $17 \%$, affected sib in family in $5 \%$, perinatal insult in $51 \%$, developmental regression in $41 \%$, early developmental delay in $51 \%$ and seizure in $75 \%$ cases were the common presenting feature. Most of them were diagnosed on the basis of clinical findings, X-ray findings, bone marrow study, liver biopsy, echocardiography and MRI findings. Lack of suspicion, lack of facility of specific enzyme assay and unavailability of treatment are the major challenges.

Conclusions: There have been significant advances in the field of LSDs but proper diagnosis and effective therapies are still not available to the patients suffering from these diseasesin Bangladesh.

Keywords: status and challenges, LSDs, Bangladesh
Volume 9 Issue I - 2019

Manzoor Hussain,' Mohammad Abdullah Al Mamun, ${ }^{2}$ Mustafa Mahbub, ${ }^{3}$ AZM Mosiul Azam, ${ }^{4}$ Humaira Rafiqa ${ }^{5}$

'Head of Paediatric Medicine and Cardiology, Bangladesh Institute of Child Health and Dhaka Shishu (Children) Hospital, Bangladesh

${ }^{2}$ Assistant Professor and Intensivist, Department of Pediatric Cardiology, Bangladesh Institute of Child Health and Dhaka Shishu (Children) Hospital, Bangladesh

${ }^{3}$ Associate Professor, Department of Pediatric Neuroscience, Bangladesh Institute of Child Health and Dhaka Shishu (Children) Hospital, Bangladesh

${ }^{4}$ Assistant Professor, Department of Pediatric Neuroscience,

Dhaka Shishu (Children) Hospital, Bangladesh

${ }^{5}$ Resident Medical Officer, Department of Pediatric

Neuroscience, Dhaka Shishu (Children) Hospital, Bangladesh

Correspondence: Prof. Manzoor Hussain, Head of Paediatric Medicine and Cardiology, Bangladesh Institute of Child Health and Dhaka Shishu (Children) Hospital, Email manzoor-hussain@hotmail.com

Received: March 06, 2017 | Published: January II, 2019

\section{Introduction}

Inborn errors of metabolism are a common cause of inherited disease $^{1}$ of which lysosomal storage diseases (LSDs) are a significant subgroup. ${ }^{2,3}$ Although the first clinical descriptions of patients with lysosomal storage disorders (LSDs) were reported at the end of the nineteenth century by Warren Tay, ${ }^{4}$ Bernard Sachs (1887; Tay-Sachs disease $)^{5}$, and by PhillipeGaucher (1882; Gaucher disease ${ }^{6}$, the biochemical nature of the accumulated products was only elucidated some 50 years later ${ }^{7}$. Considerably more time was then required for the demonstration by Hers that there was a link between an enzyme deficiency and a storage disorder (Pompe disease). ${ }^{8}$

At present, more than 50 LSDs are known. The majority of these result from a deficiency of specific lysosomal enzymes. In a few cases, non-enzymatic lysosomal proteins or non-lysosomal proteins involved in lysosomal biogenesis are deficient. Most LSDs are autosomal recessive conditions, with the exception of X-linked Fabry, Hunter (mucopolysaccharidosis type II, MPS-II) and Danon disease. ${ }^{9}$

The combined incidence of LSDs is estimated to be approximately 1:5,000 live births ${ }^{2}$, but the true figure is likely greater when undiagnosed or misdiagnosed cases are accounted for. Common to all LSDs is the initial accumulation of specific macromolecules or monomeric compounds inside organelles of the endosomalautophagic-lysosomal system. Initial biochemical characterization of stored macromolecules in these disorders led to the implication of defective lysosomal enzymes as a common cause of pathogenesis. ${ }^{10}$

The common biochemical hallmark of these diseases is the accumulation of undigested metabolites in the lysosome. Lysosomal accumulation activates a variety of pathogenetic cascades that result in complex clinical pictures characterised by multi-systemic involvement. ${ }^{3,11}$ Phenotypic expression is extremely variable, as it depends on the specific macromolecule accumulated, the site of production and degradation of the specific metabolites, the residual enzymatic expression and the general genetic background of the patient. In LSDs, buildup of material begins in infancy and progressively worsens, often affecting several organs including internal organs and the central nervous system. Usually, tissue damage is progressive, creating a window of opportunity for future therapies.

Technological developments in newborn and population screening, biomarker discovery for monitoring treatment and rapid high throughput DNA sequencing are having a great impact on the diagnostic procedure for symptomatic patients with lysosomal storage diseases. The use of dried blood spots, initially for newborn screening, has stimulated the introduction of automated, rapid 
and more sensitive methods for the assay of lysosomal enzymes, including the synthesis of novel substrates. ${ }^{12}$

The prospects for treatment of LSDs fall into a number of categories: Enzyme Replacement Therapy (ERT) or gene therapies, to restore the function of the missing protein: substrate reduction therapies, aimed at reducing the amount of storage material produced; small molecules, to rescuemis-folded or unstable enzymes; cellular therapies to restore the injured cell; stimulating survival pathways or; inhibiting pathways that cause cell death. ${ }^{13-18}$

With the fall of deaths of children from diarrhoea, respiratory tract infections and malnutrition due to availability of improved health services and diet, more children are now surviving and visiting hospital with genetic disorders. It has been observed that the need for genetic services arises in a country when the rate of infant mortality falls below 46/1000 births. ${ }^{19}$ In Bangladesh infant mortality is now $31 / 1000$ births. ${ }^{20}$ With the improvement of overall health services now the burden of genetic disorders are emerging.

The important role of genetics in pediatric illness has been increasingly recognized, but the true impact has not been well delineated. The intuitive solution to such a problem is early identification and genetic counseling. For this, a correct diagnosis is necessary for treatment, nature and prognosis, genetic risk for family and prenatal diagnosis.

\section{Materials and methods}

A retrospective analysis was done in the Pediatric Neuroscience Department of Dhaka Shishu (Children) Hospital, Bangladesh. Suspected neurometabolic disorders were selected from July 2007 to July 2016.The diagnosis of most neurometabolic disorderswere done after accurate clinical evaluation and findings of some laboratory tests including the analysis of some urinary metabolites, TMS (done from India), bone marrow study and liver biopsy.Total 181 suspected cases of neurometabolic disorders were identified. From these neurometabolic disorders LSDs were selected. Data were alalyzed by using SPSS version 21.

\section{Results}

During the study period total 181 neurometabolic diseases were identified among them LSDs were 79(43.64\%), biotinase deficiency $23(12.0 \%)$, Wilson disease $21(11.60 \%)$, urea cycle disorder in $12(6.63 \%)$, mitochondrial disorder $7(3.87 \%)$ and fatty acid oxidation 9(4.97\%) (Figure 1).

Among LSDs leukodystrophy was 24(30.38\%), GM-1 7(8.86\%), TaySaches disease 10(12.67\%), Gaucher disease 15(18.99\%), Niemann pick disease $6(7.59 \%)$, Sandhoff's disease 2(2.53\%), Neuronal ceroidlipofuscinoses 4(5.06\%), Mucopolysaccharidosis $7(8.86 \%)$ and Glycogen storage disease $4(5.06 \%)$ (Figure 2).

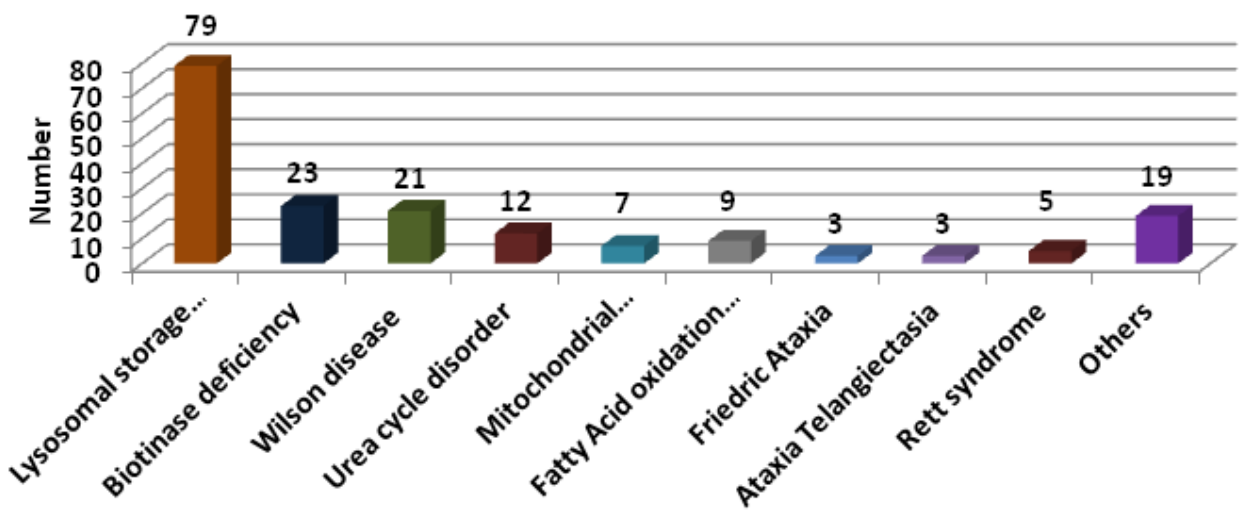

Figure I Distribution of neurometabolic diseases during study period $(n=|8|)$.

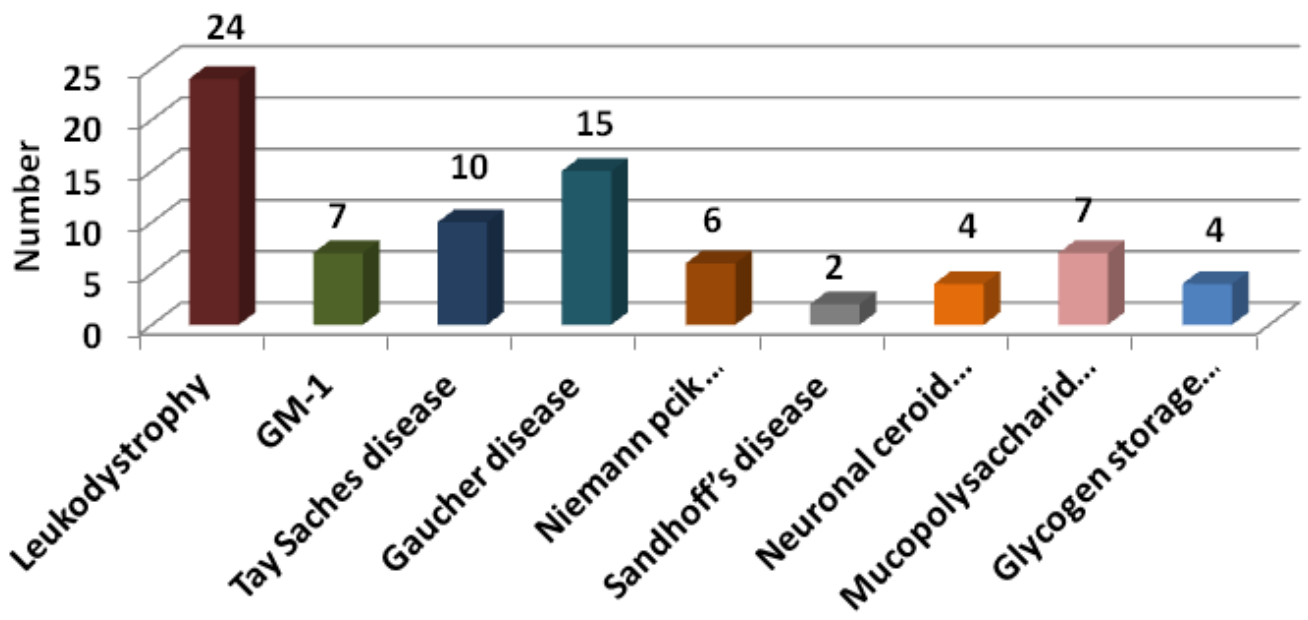

Figure 2 Distribution of Lysosomal Storage Disorders $(n=79)$. 
Male were predominant (64\%) and male female ratio was 1.77:1 (Figure 3).

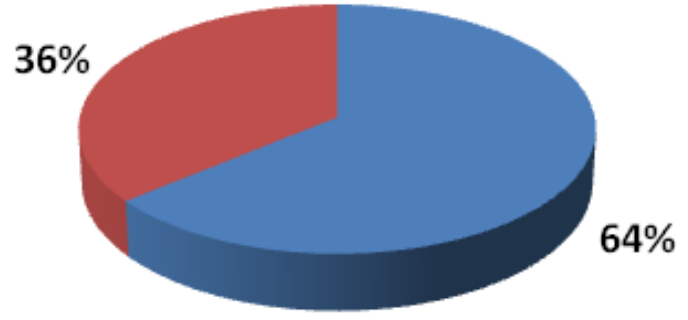

Figure 3 Sex distribution of study population $(n=79)$.

Among the cases $31 \%$ were 1 month to 1 year of age, 53\% 1 year to 5 year and $16 \%$ were $>5$ years of age (Figure 4 ).

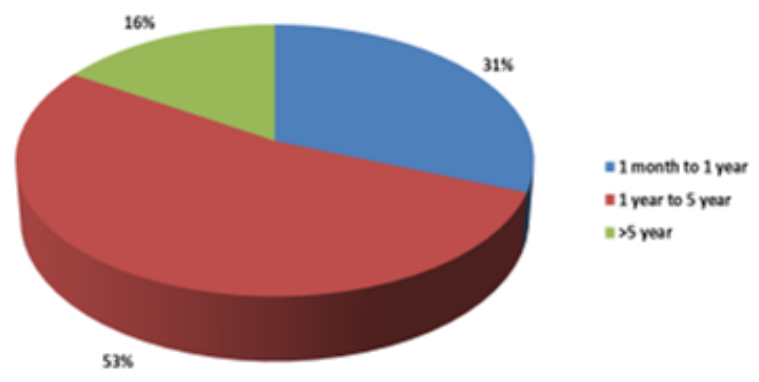

Figure 4 Age distribution of study population $(n=79)$.

Table 2 Diagnostic approach and limitations $(n=79)$
Consanguinity was present in $31 \%$ cases, perinatal insult in $51 \%$, sibling death in $17 \%$, affected sibling in $5 \%$, regression of development in $41 \%$, early developmental delay in $51 \%$ and seizure was present in $75 \%$ cases (Table 1 ).

Table I Background history of study cases (multiple response)

\begin{tabular}{lccc}
\hline & Present & Absent & Not known \\
\hline H/O Consanguinity & $31 \%$ & $68 \%$ & $1 \%$ \\
H/O Perinatal insult & $51 \%$ & $47 \%$ & $2 \%$ \\
H/O Sibling death & $17 \%$ & $65 \%$ & $18 \%$ \\
Affected sibling & $5 \%$ & $76 \%$ & $19 \%$ \\
Regression of development & $41 \%$ & $57 \%$ & $2 \%$ \\
Early developmental delay & $51 \%$ & $49 \%$ & $2 \%$ \\
Seizure & $75 \%$ & $24 \%$ & $1 \%$ \\
\hline
\end{tabular}

Diagnosis of Leukodystrophy was supported by demeylating changes in periventricular white matter with predominance over the frontal area in MRI, in 2 cases of GM1 foamy cells was found in bone marrow, in Tay Saches disease hyperintensethalamai in T2 image of MRI, in Mucopolysaccharidosis urine for MPS was positive in one case done from India, Gaucher disease was diagnosed with Gaucher cell-lacy striated cytoplasm in bone marrow. Glycogen storage disease - GSD II was diagnosed with the help of liver biopsy, Neuronal ceroidlipofuscinoses was diagnosed with EEG findings of epiloeptiform discharges with each photic stimulus at low threshold and decreased T2 signal in thalamai in MRI, Niemannpcik Disease with vacuolated/foamy cells in bone marrow and Sandhoff's disease by cherry red spot (Table 2).

\begin{tabular}{|c|c|c|c|}
\hline Storage disease & Total & Diagnostic approach & Diagnostic limitations \\
\hline Leukodystrophy & 24 & $\begin{array}{l}\text { Clinical features and MRI findings (Demeylating changes } \\
\text { in periventricular white matter with predominance over the } \\
\text { frontal area) }\end{array}$ & $\begin{array}{l}\text { Lack of facilities for specific enzyme assay } \\
\text { (Aryl sulfatase A) }\end{array}$ \\
\hline Gangliosidosis - (GM1) & 7 & $\begin{array}{l}\text { Clinical features and X-ray findings and in } 2 \text { cases foamy } \\
\text { cells in bone marrow }\end{array}$ & $\begin{array}{l}\text { Lack of facilities for specific enzyme assay } \\
\text { (acid beta Galactosidase) }\end{array}$ \\
\hline Tay Saches disease & 10 & $\begin{array}{l}\text { Clinical features and MRI(hyperintensethalamai in T2 image) } \\
\text { and opthalmological (cherry red spot)findings }\end{array}$ & $\begin{array}{l}\text { Lack of facilities for specific enzyme } \\
\text { assay(Hexose aminidase A) }\end{array}$ \\
\hline Mucopolysaccharidosis & 7 & $\begin{array}{l}\text { Clinical features and X-ray findings for dystosis multiplex } \\
\text { and Urine for MPS Positive (1 case, done in India) }\end{array}$ & $\begin{array}{l}\text { Lack of facilities for specific enzyme } \\
\text { assay (L-iduronidase, Iduronatesulfatase, } \\
\mathrm{N} \text {-acetylglucosaminidase, } \beta \text {-galactosidase) }\end{array}$ \\
\hline Gaucher disease & 15 & $\begin{array}{l}\text { Clinical features, in 1 case BM findings (Gaucher cell-lacy } \\
\text { striated cytoplasm) }\end{array}$ & $\begin{array}{l}\text { Lack of facilities for specific enzyme assay } \\
\text { (beta glucocerebrosidase) }\end{array}$ \\
\hline $\begin{array}{l}\text { Glycogen storage disease } \\
\text { - GSD II }\end{array}$ & 4 & Clinical features andliver biopsy findings & $\begin{array}{l}\text { Lack of facilities for specific enzyme assay } \\
\text { (acid glucosidase) }\end{array}$ \\
\hline $\begin{array}{l}\text { Neuronal } \\
\text { ceroidlipofuscinoses }\end{array}$ & 4 & $\begin{array}{l}\text { Clinical features and specific EEG findings (epiloeptiform } \\
\text { discharges with each photic stimulus at low threshold)and } \\
\text { MRI findings(decreased T2 signal in thalamai) }\end{array}$ & $\begin{array}{l}\text { Lack of facilities for specific enzyme assay } \\
\text { (palmitoyl-protein thioesterase in CLN1 type } \\
\text { and tripeptyl-peptidase } 1 \text { activity in CLN2 } \\
\text { type) }\end{array}$ \\
\hline Niemannpcik Disease & 6 & Clinical features and vaculated/foamy cells in bone marrow & $\begin{array}{l}\text { Lack of facilities for specific enzyme assay } \\
\text { (acid sphingomyelinase) }\end{array}$ \\
\hline Sandhoff's disease & 2 & $\begin{array}{l}\text { Clinical features and opthalmological (cherry red spot) } \\
\text { findings }\end{array}$ & $\begin{array}{l}\text { Lack of facilities for specific enzyme assay } \\
\text { (Hexose aminidase A) }\end{array}$ \\
\hline \multicolumn{4}{|c|}{$\begin{aligned} & \text { Discussion } \text { for early diagnosis of LSDs. None of our cases were diagnosed } \\
& \text { prenatally as prenatal diagnosis is not available in Bangladesh. In } \text { Individual genetic disorders are rare, but, in the aggregate, genetic } \\
& \text { cases where treatment is not feasible, early diagnosis of LSDs remains } \\
& \text { disorders are common. A review of pediatric mortality data shows that } \\
& \begin{array}{l}23 \% \text { of infant deaths are due to genetically determined disorders. }{ }^{21} \text { For } \\
\text { important for providing parents with realistic information about their } \\
\text { this early identification is must. Prenatal diagnosis is very important }\end{array}\end{aligned} \quad \begin{array}{l}\text { child's prognosis. } \\
\end{array}$} \\
\hline
\end{tabular}


The age of clinical onset and spectrum of symptoms exhibited amongst different LSDs vary, depending on the degree of protein function affected by specific mutations, the biochemistry of the stored material, and the cell types where storage occurs. The classical clinical presentation of an LSD is a neurodegenerative disease of infancy/ childhood but adult-onset variants also occur. ${ }^{22}$ In this study only $31 \%$ cases were diagnosed within 1 year of age and $53 \%$ were diagnosed within 5 years of age.

In the majority of LSDs, CNS involvement is common and neurodegeneration can occur in multiple brain regions (e.g., thalamus, cortex, hippocampus, and cerebellum). Neuropathology in LSDs involves unique temporal and spatial changes, which often entails early region-specific neurodegeneration and inflammation, before global brain regions are affected. ${ }^{23}$ In this study features of CNS involvement were common and $51 \%$ presented with early developmental delay, $41 \%$ with regression of development and $75 \%$ with seizure.

Pediatricians play a central role in the diagnosis of LSDs. Unfortunately, due to the rarity of the disorder, it is often misdiagnosed. To properly diagnose LSDs, clues about the anatomic level of the underlying abnormality and the likely pathology should be obtained from a medical history and physical examination. Majority of the cases in this study were diagnosed clinically with few supportive investigations. In this study diagnosis of Leukodystrophy was supported by demeylating changes in periventricular white matter with predominance over the frontal area in MRI, in 2 cases of GM1 foamy cells was found in bone marrow, in Tay Saches disease hyperintensethalamai in T2 image of MRI, in Mucopolysaccharidosis urine for MPS was positive in one case (done from India), Gaucher disease was diagnosed with Gaucher cell-lacy striated cytoplasm in bone marrow. Glycogen storage disease - GSD II was diagnosed with the help of liver biopsy, Neuronal ceroidlipofuscinoses was diagnosed with EEG findings of epiloeptiform discharges with each photic stimulus at low threshold and decreased T2 signal in thalamai in MRI, Niemannpcik disease with vaculated/foamy cells in bone marrowand Sandhoff's disease by cherry red spot.

The diagnosis of most LSDs after accurate clinical/paraclinical evaluation, including the analysis of some urinary metabolites is based mainly on the detection of a specific enzymatic deficiency. In these cases, molecular genetic testing (MGT) can refine the enzymatic diagnosis. ${ }^{24}$ Laboratories used for enzymology and molecular diagnostics should be experienced and of high quality as evidenced by participation in quality assurance and proficiency testing programs. Unfortunately enzymatic detection of LSDs are yet not possible in Bangladesh.

While the ability to diagnose genetic conditions continues to grow almost exponentially, there remains a profound time gap between the capacity to diagnose and the capacity to treat. Sadly, to date there are very few effective therapies for LSDs. It is likely that for some time there will be many more genetic diseases diagnosed than can be treated. ${ }^{25}$ This phenomenon has resulted in the emergence of a new class of patient: the presymptomatic ill. These are persons who have been diagnosed with LSD for which there is no treatment. In many cases they may not show symptoms of the disease for a number of years. No one knows what the psychological and social implications of the diagnostic/therapy gap will be. What might it be like for a young girl to know at eight years of age that she has the gene for LSD a disease whose debilitating symptoms soon? How will that knowledge affect her life's choices? More importantly, how will that knowledge affect the choices of her parents as they nurture her? Will they discourage long-term life planning? ${ }^{25} \mathrm{We}$ are facing this kind of question every day.

The majority of patients receive some benefit from ERT in LSDs, however the drug response is somewhat dependent on disease burden, previous damage that occurred prior to the start of ERT, and the patient's individual disease complications. On average the drug cost per year for ERT is $\$ 200,000-\$ 300,000$ in the United States, depending on the individual's weight, prescribed dose, and the average wholesale price of the drug. ${ }^{26}$ For many countries, expense is a large consideration in the treatment of LSDs. Insurance plans may have a lifetime cap for drug expenses that can be rapidly exhausted with most of the available therapies. Some health systems demand that each new therapy be demonstrated to be cost-effective, a difficult challenge for these rare disorders. Some have designed special funding programs for rare disease treatments. Less affluent countries are unable to afford the drugs or routinely use a low dose. Some help is provided to many patients without resources by assistance programs from the drug companies; however, most individuals worldwide receive supportive and palliative care, at best. ${ }^{27} \mathrm{As}$ Bangladesh is a low income country this huge cost is difficult to bear for any patients suffering from LSDs. So insurance policy and health system should be modified for this kind of illness.

Patients with LSD often need multidisciplinary care that should ideally be provided through a team approach including medical genetics, hematology, cardiology, neurology, ophthalmology, anesthesiology, etc. As LSDs becomes more widespread, there will be an increasing need for physicians trained in the care of these patients, particularly biochemical geneticists.

\section{Conclusions}

There have been significant advances in the field of LSDs but proper diagnosis and effective therapies are still not available to the patients suffering from these diseases in Bangladesh.

\section{Acknowledgments}

None.

\section{Conflict of interest}

The author declares no conflict of interest.

\section{References}

1. Burton BK. Inborn errors of metabolism in infancy: a guide to diagnosis. Pediatrics. 1998;102:E69.

2. Fuller M, Meikle PJ, Hopwood JJ. Epidemiology of lysosomal storage diseases: an overview. Oxford: Oxford Pharma Genesis; 2006. Chapter 2 .

3. Ballabio A, Gieselmann V. Lysosomal disorders: from storage to cellular damage. Biochim Biophys Acta. 2009;1793(4):684-696.

4. Nardi T. Symmetrical changes in the region of the yellow spot in each eye of an infant. Trans Opthalmol Soc. 1881;1: 55-57.

5. Sachs B. On arrested cerebral development with special reference to cortical pathology. J Nerv Ment Dis. 1887;14:541-554.

6. Gaucher PCE: De l'epitheliomaprimitif de la rate, hypertrophieidiopathique de la rate sans leucemie. Academic thesis, Paris, France. 1882 
7. Capper A, Epstein H, Schless RA. Gaucher's disease. Report of a case with presentation of a table differentiating the lipoid disturbances. Am J Med Sci.1934;188:84-10.

8. Hers HG. $\alpha$-Glucosidase deficiency in generalized glycogen-storage disease (Pompe's disease). Biochem J.1963,86:11.

9. Meikle PJ, Hopwood JJ, Clague AE, et al. Prevalence of lysosomal storage disorders. JAMA. 1999;281(3):249-254.

10. Platt FM, Walkley SU, Winchester B. Primary defects in lysosomal enzymes. In: Platt FM, Walkley SU, editors, Lysosomal Disorders of the Brain. UK: Oxford University Press; Oxford. 2004: 81-130.

11. Vitner EB, Platt FM, Futerman AH. Common and uncommon pathogenic cascades in lysosomal storage diseases. J Biol Chem. 2010;285(27):20423-20427.

12. Winchester B. Lysosomal diseases: diagnostic update. Journal of Inherited Metabolic Disease. 2014;37(4):599-608.

13. Desnick RJ, Schuchman EH. Enzyme replacement and enhancement therapies: lessons from lysosomal disorders. Nat Rev Genet 2002;3(12):954-966.

14. Platt FM, Jeyakumar M. Substrate reduction therapy. Acta Paediatr Suppl 2008;97(457):88-93.

15. Balch WE, Morimoto RI, Dillin A, et al. Adapting proteostasis for disease intervention. Science 2008; 319(5865):916-919.

16. Shihabuddin LS, Cheng SH. Neural stem cell transplantation as a therapeutic approach for treating lysosomal storage diseases. Neurotherapeutics 2011;8(4):659-667.

17. Vincent M, Sayre NL, Graham MJ, et al. Evaluation of an anti-tumor necrosis factor therapeutic in a mouse model of Niemann-Pick C liver disease. PLoS One 2010;5(9):e12941.
18. Simonaro CM, Ge Y, Eliyahu E, et al. Involvement of the Toll-like receptor 4 pathway and use of TNF-alpha antagonists for treatment of the mucopolysaccharidoses. Proc Natl Acad Sci U S A 2010;107(1):222227.

19. Primary health care approaches for prevention and control of congenital and genetic disorders. Report of WHO meeting, Cairo, Egypt, 1999.

20. Infant Mortality Rate. http://data.worldbank.org/indicator/SP.DYN IMRT.IN

21. Hoyert DL, Freedman MA, Strobino DM, et al. Annual summary of vital statistics: 2000. Pediatrics 108(6):1241-1255.

22. Wraith JE. Lysosomal disorders. Semin Neonatol. 2002;7(1):75-83.

23. Vitner EB, Platt FM, Futerman AH. Common and uncommon pathogenic cascades in lysosomal storage diseases. $J$ Biol Chem 2010;285(27):20423-20427.

24. Filocamo M, Morrone A. Lysosomal storage disorders: Molecular basis and laboratory testing. Hum Genomics.2011;5(3):156-169.

25. Mitchell CB, Kilner JF. Challenges for the Future of Genetic Medicine. Does God Need Our Help? Cloning, Assisted Suicide,\& Other Challenges in Bioethics (Tyndale 2003).

26. Brady RO. Enzyme replacement for lysosomal diseases. Annual Review of Medicine. 2006;57:283-296.

27. Wang RY, Bodamer OA, Michael S Watson MS, et al. Lysosomal storage diseases: Diagnostic confirmation and management of presymptomatic individuals. Genetics in Medicine. 2011;13:457-484. 